\title{
Effects of soil pH, Total Organic Carbon and texture on fate of Polycyclic Aromatic Hydrocarbons (PAHs) in soils
}

\author{
*Emoyan O.O., Akporido S.O. and Agbaire P.O. \\ Environmental Chemistry and Waste Management Research Group, Formally, Environmental and Food Chemistry Research Group, \\ Department of Chemistry Delta State University, P.M.B.1 Abraka, Nigeria. \\ Received: 24/02/2017, Accepted: 01/02/2018, Available online: 22/02/2018 \\ *to whom all correspondence should be addressed: e-mail: onostica_pub@yahoo.com
}

\section{Abstract}

Polycyclic aromatic hydrocarbons (PAHs) are a group of quotidian organic compounds having between two and six condensed aromatic rings braced in angular, cluster or linear forms possessing hydrogen and carbon atoms only. This work aims to evaluate the physicochemical characteristics of soil as determinants of PAHs distribution and fate. The study area is situated on the Benin River beneath the convergence of Jamieson River and River Ethiope. The weather and climatic conditions of the area are of the Niger Delta region. Sixteen priority PAHs were determined in ten sample stations. Upon extraction, purification and quantification of PAHs was done using GCFID. According to the methods of Walkey-Blacks, Black and Bouyoucus, soil total organic carbon, $\mathrm{pH}$ and texture were analyzed respectively. Four replicate samples were chosen to create a composite and used as quality control. KruskalWallis test with tied rank was used to determine a causative correlation between soil physicochemical parameters and $\sum$ PAHs. Results showed that the study area is contaminated with high concentration of PAHs ranging from $60.76-271.11239 \mu \mathrm{g} \cdot \mathrm{g}^{-1}$ with higher percentages of HPAHs i.e. PAHs with LogKow>4.0. It is observed that observed alkaline $\mathrm{pH}$ favour significant fungal, asperigellus and microbial degradation of PAHs, and hinder photocatalytic degradation. However, acidification with elemental sulfur, ferrous sulfate and aluminum sulfate could enhance photo-catalytic degradation. Results of TOC and soil structure do not favour significant degradation of HPAHs. Kruskal-Wallis tied rank test revealed that there was a positive significant difference between $\mathrm{pH}$, TOC, percentage clay, and silt fractions with $\Sigma$ PAHs concentrations since calculated $\mathrm{K}$ is greater than critical $\mathrm{K}_{0.05}, \mathrm{P}<0.05$ except percentage of sand fractions and $\sum \mathrm{PAHs}$ with $\mathrm{P}>0.05$. A substantial percentage of these $\mathrm{PAHs}$ have no anthropic origin and are characterized as having high lipo-affinity, semi-volatility and resistance to biotic and/or abiotic transformations. Due to edaphic factors the observed HPAHs may partially degrade with the consequent formation of highly toxic by-products. Therefore, oral or dermal ingestion of soil in the study area may cause significant exposure of the human population to these PAHs. Risk assessment and probable toxicity effects on animal diversity should be carried out in soil samples of the study area.

Keywords: Soil TOC, $\mathrm{pH}$ and Texture, PAHs Availability, Degradation and Fate.

\section{Introduction}

Polycyclic aromatic hydrocarbons (PAHs) are a class of quotidian organic substances having between two and six condensed aromatic rings fixed in angular, cluster or linear forms and bearing hydrogen and carbon atoms only, (Zeng et al., 2000; WHO, 2002; Emoyan, et.al., 2015c). Several research findings have established that there are various soil concentrations of PAHs from point and/or diffuse contamination, (Soleimani et al., 2013; Valentin et.al., 2013). They are naturally produced during forest fires and volcanic eruptions. Anthropogenically, PAHs originate mainly from partial combustion of fossil fuel, wood, industrial, domestic and commercial waste, automobile fumes, petroleum, and derivative spills, (Dabastanni and Ivanov, 1999). Polycyclic aromatic hydrocarbons are nondipole hydrophobic compounds that are soluble in water. They decrease with increase in molecular weight and show low affinity for fine particulate matter hence sediment and soil are major sinks for PAHs, (Dabastanni and Ivanov, 1999; CCME, 2008). Henry's Constant, Octanol-Water Partition Coefficient (Kow), Organic Carbon-Water Partition Coefficient (Koc), aqueous solubility and vapour pressure are distinct chemical variables that are useful in predicting bioaccumulation, multimedia-partitioning behavior, environmental fate, resistance to bio-chemical degradation and toxicity of these persistence organic compounds (POC), (CCME, 2008; WHO, 2002; Emoyan et al., 2015ab). Polycyclic aromatic hydrocarbons have carcinogenic properties, affect human reproduction as well as giving rise to respiratory toxicity. They are, therefore, grouped as 'priority pollutants' (CCME, 2008).

Soil is an unconsolidated biogeochemical material on the surface of the earth that supports evidence of life existence. Its composition includes: organic and inorganic elements/matter, air and water (Haygarth and Ritz, 2009; Robinson et. al., 2012; Valentin et al., 2013). It provides the 
essentials of fiber, fodder, food and fuel. Soil is also involved in ecosystem services such as reclamation of carbon, biological control of pests, screening and storage of water and regulation of the atmosphere, (Haygarth and Ritz, 2009; Robinson et al., 2012; Valentin et al., 2013). Therefore, its quality is important to the humans and environment. Soil physicochemical properties such as $\mathrm{pH}$, TOC, sand, clay and silt are also relevant in the evaluation of PAHs behavior in terms of bioavailability, environmental fate, multi-media partitioning behavior, and resistance to biotic and abiotic degradation, (CCME 2008; Emoyan et al., 2015a).

The behaviour of hydrophobic contaminants in soil is basically governed by a variety of complex processes which include; volatilization, biological and chemical degradation, sorption-desorption, runoff, leaching and uptake by plants. These processes directly or indirectly determine the rate and transport of these PPs within the soil and transport from air to food, soil or water. These processes are determined by the physicochemical properties of the contaminants, and the biochemical and hydraulic characteristics of the soil, (Okere and Semple, 2012; Robinson et al., 2012)

Anthropogenic or natural soil contamination could compromise the ability of the natural ecosystem to provide its essentials of fodder, fiber, food and fuel. The evaluation of soil physicochemical characteristics is useful to evaluating the vulnerability of PAHs to abiotic and or biotic degradation, toxicity potentials and their effect on humans since research has shown that colloidal soil particles $<0.002 \mathrm{~nm}$ have a larger surface area with high tendency to bind more to organic contaminants. Similarly, TOC usually exhibits a positive correlation with organic contaminants while biochemical degradation of organic contaminants such as PAHs depends on the $\mathrm{pH}$ condition of the environment. This investigation is aimed at determining soil physicochemical characteristics as determinants of $\mathrm{PAHs}$ degradation and fate which is of significant interest in bioremediation.

\section{Materials and methods}

\subsection{Study Area Description}

The study location is situated on the River Benin beneath the convergence of River Jamieson and Ethiope, (Emoyan, 2014; Emoyan et al., 2015abc, and Opafunson, 2007). It has an approximate human population density of 142,652 with geographical coordinates of Latitude $5^{0} 54^{\prime}-5^{0} 9^{\prime} \mathrm{N}$ and Longitude $5^{\circ} 40^{\prime}-5^{\circ} 66^{\prime} \mathrm{E}$ as shown in Figure 1 . The weather and climatic conditions are of the Western Niger Delta located in the Gulf of Guinea on Latitude $3^{\circ} \mathrm{N}$ and $6^{\circ} \mathrm{N}$ Longitude $5^{\circ}$ and $8^{\circ} \mathrm{E}$, i.e. rain forest zone, high humidity and temperature.

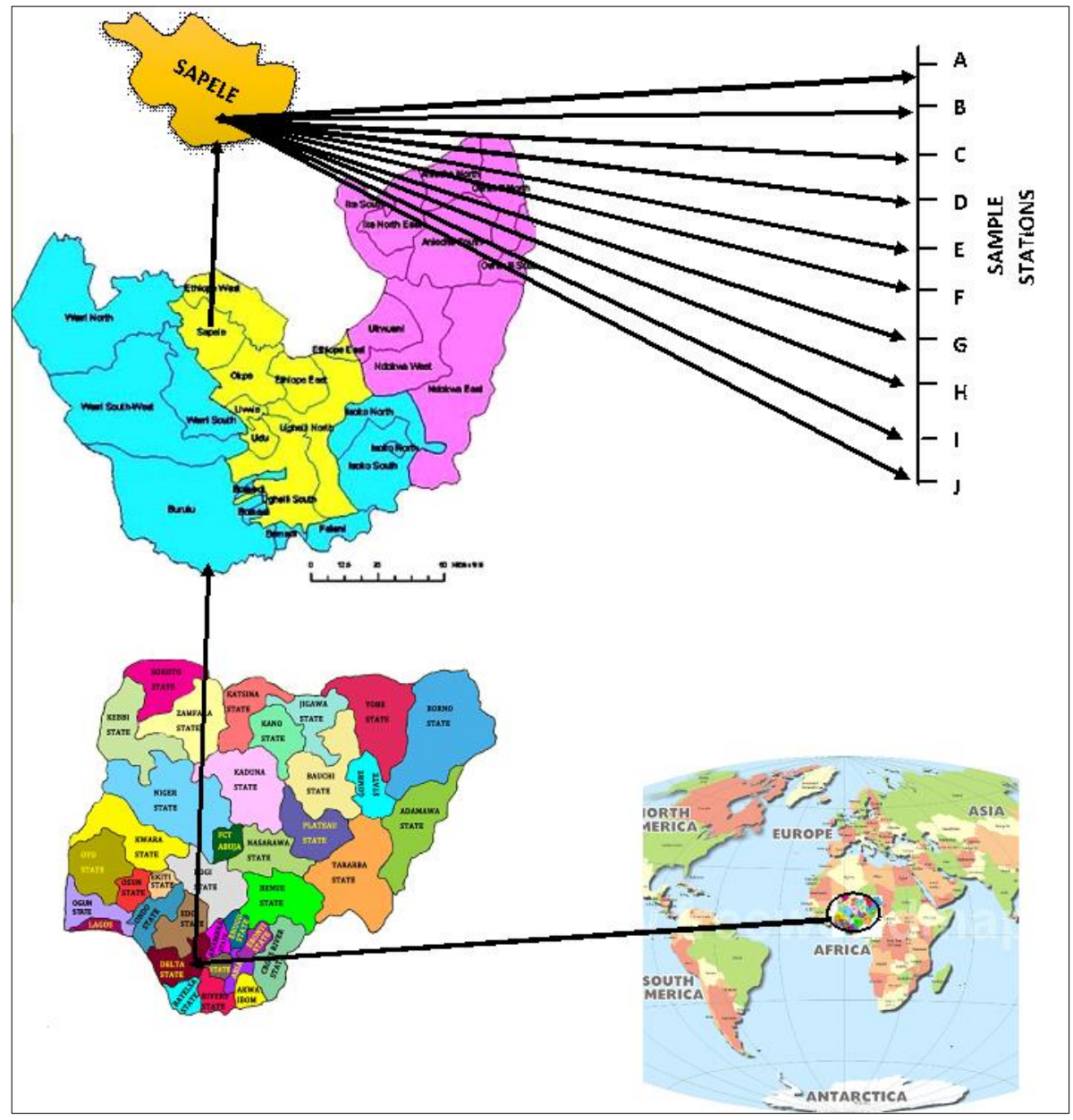

Figure 1. Map of the study area and locations of sampling stations 


\subsection{Sample Collection and Preparation}

Soil samples were monitored in top and bottom soil for eight months in ten sample sites (160 samples) as described in Figure 1. Residual roots and stones were separated from each soil sample and stored in black polyethylene bags in the dark to prevent microbial degradation, evaporation and photo-oxidation of analytes before digestion, extraction and quantification and analyses, (OIEWG, 1999; Cavalcante et al., 2009; Emoyan, 2014; Emoyan et al., 2015abc).

\subsection{Extraction and Analysis}

The method of Cavalcate et.al., (2009) as modified in Emoyan, (2014) and Emoyan, et.al., (2015a,b,c) was used. Thus $10 \mathrm{~g}$ of dried sample was extracted continuously with $60 \mathrm{~mL}$ of $\mathrm{CH}_{2} \mathrm{Cl}_{2}$ for $8 \mathrm{hrs}$. As internal standard, 4 deuterated PAHs mixtures of d12-perylene, d10-phenanthrene, d10acenaphthene, and d12-chrysene were added to the sample. Methylene chloride was removed using rotary evaporator at $30-35{ }^{\circ} \mathrm{C}$ thereafter, the extract was purified by solid phase extraction after retrieval with 3 portions of $1 \mathrm{~mL}$-hexane. Using $8 \mathrm{~g}$ of Aluminum Oxide $\left(\mathrm{Al}_{2} \mathrm{O}_{3}\right)$, hydrocarbons and other hydrophobic contaminants were removed using $40 \mathrm{~mL}$ of $\mathrm{n}$-hexane after the addition of the sample to the column. Elution of PAHs was done using $40 \mathrm{~mL}$ of $\mathrm{CH}_{2} \mathrm{Cl}_{2}$ and the resultant solute was re-dissolved in $1 \mathrm{~mL}$ of isooctane after drying. Polycyclic aromatic hydrocarbons determination was carried out using interfaced flame ionization detector gas chromatograph (Varian model 300). The initial oven temperature was $60^{\circ} \mathrm{C}$ for $10 \mathrm{~min}$, followed by a step-wise increase of $5{ }^{\circ} \mathrm{C} \mathrm{min}^{-1}$ up to $120^{\circ} \mathrm{C}$ and finally a step-wise increase of $3{ }^{\circ} \mathrm{C} \mathrm{min}-1$ up to $300^{\circ} \mathrm{C}$. The injector and detector temperatures were $200{ }^{\circ} \mathrm{C}$ and $300{ }^{\circ} \mathrm{C}$, respectively. Concentration evaluation was based on Supelco and Merck using the internal standard. The detection limit is $0.001 \mu \mathrm{g} \mathrm{g}{ }^{-1}$. Concentration of PAHs was quantified and qualified by extrapolating from the given standards.

\subsection{Total Organic Carbon}

The method of Walkey-Black, (1934) was used. Thus, $1 \mathrm{~g}$ of soil sample was weighed into $200 \mathrm{~mL}$ Erlenmeyer flask. Ten milliliters of $0.5 \mathrm{M} \mathrm{K}_{2} \mathrm{Cr}_{2} \mathrm{O}_{7}$ solution was added to the flask. After gentle stirring, $20 \mathrm{~mL}$ of Conc. $\mathrm{H}_{2} \mathrm{SO}_{4}$ was added and shaken for $30 \mathrm{~min}$. After the addition of $100 \mathrm{~mL}$ of $\mathrm{H}_{2} \mathrm{O}$ to the solution, $10 \mathrm{~mL}$ of O-phosphoric acid was added to the solution. Finally, 4 drops of phenolphthalein indicator were added, and the solution was titrated against $0.25 \mathrm{M}$ of Ammonium Iron (II) Sulfate $\mathrm{Fe}\left(\mathrm{NH}_{4}\right) \mathrm{SO}_{4}$. A control was similarly treated.

\section{5. $p H$ (Soil $p H$ in water)}

The method of Black, (1965) was used, thus $20 \mathrm{~g}$ of $2 \mathrm{~mm}$ sieved and air-dried sample was added into $50 \mathrm{~mL}$ beaker and $20 \mathrm{~mL}$ distilled water was added and allowed to stay for $30 \mathrm{~min}$ with occasional stirring with a glass rod, the electrode of a calibrated $\mathrm{pH}$ meter ( $\mathrm{pH} 9.2$ and $\mathrm{pH} 4$ buffer) was inserted into the partially settled suspension and the $\mathrm{pH}$ was measured.

\subsection{Soil Texture (Pipette method)}

The method Bouyoucus, (1951), was used, thus $50 \mathrm{~g}$ of dry soil sample was added into $100 \mathrm{~mL}$ beaker and $5 \mathrm{~mL}$ of $\mathrm{H}_{2} \mathrm{O}_{2}$ was added to remove organic matter. Finally, $5 \mathrm{~mL}$ of $\mathrm{H}_{2} \mathrm{O}_{2}$ was added to the mixture until oxidation is complete. After drying the sample on a hot plate, $50 \mathrm{~mL}$ of $5 \%$ calgon solution was added. Using a ground shaker, the mixture was shaken for 2 hours. Using a $0.053 \mathrm{~mm}$ sieve, the sample was washed into a 1-liter measuring cylinder until it became clear. The final volume of the cylinder was noted. After shaking the cylinder vigorously, $20 \mathrm{~mL}$ of the colloidal solution was oven-dried, and the weight of the dry sample was noted, this is the weight of the clay and silt. After 2 hours, another $20 \mathrm{~mL}$ of the remaining sample was collected and oven-dried. The weight was noted, this is the weight of clay.

\subsection{Quality Control}

Reagents are of chromatographic grade. Equipments, containers and apparatus were cleaned to avoid cross contamination of analytes during sampling and preparation. Four unit-samples were added to form a unit.

\subsection{Approach to Analysis of Data}

To relate soil physicochemical characteristics to the concentrations of PAHs, a non-parametric analysis of variance i.e. Kruskal-Wallis test with tied rank, $\mathrm{H}=12 \mathrm{n}(\mathrm{n}+1) \sum \mathrm{ki}=1 \mathrm{R} 2 \mathrm{ini}-3(\mathrm{n}+1)$ was performed on the mean data using Zigma Plot Version 13.

\section{Results and discussion}

\subsection{Distribution of Physicochemical and PAHs Properties}

The mean physicochemical properties and mean PAHs concentrations of 160 samples are summarized in Table 1 and Figures 2, 3, and 4. Results showed that the physicochemical properties are distributed and presented in the following order of minimum to maximum: $\mathrm{pH} \mathrm{I}<\mathrm{G}$, TOC $F<G$, sand $F<I$, clay $I<D$ and Silt $H<F$. Similarly, the $\mathrm{PAHs}$ are distributed in sample stations in the following order of minimum to maximum: Nap $D>A, A c y F \& J>G$ Ace $\mathrm{H}>\mathrm{A}$, Flu $\mathrm{G}>\mathrm{C}$, Phe $\mathrm{D}>\mathrm{B}$, Ant $\mathrm{A}>\mathrm{F}$ Flt $\mathrm{C}>\mathrm{I}$, Pyr $\mathrm{G}>\mathrm{I}$ Chr G>I, B[a]a A > I, B[a]p G > I, B[b]f H $>$ I, B[k]f H $>$ I, $\mathrm{B}$ [ghi]p $\mathrm{E}>\mathrm{I}, \mathrm{I}[123 \mathrm{~cd}$ \}p $\mathrm{F}>\mathrm{I}, \mathrm{D}[\mathrm{ah}] \mathrm{a} \mathrm{F}>\mathrm{H}$ and $\Sigma \mathrm{PAHs} \mathrm{G}>\mathrm{I}$.

\section{2. $\mathrm{pH}$ and $\mathrm{PAHs}$ Fate}

The study area recorded mean alkaline $\mathrm{pH}$ range of 7.18 and 7.53 with mean PAHs range of $60.76-271.11239$ $\mu \mathrm{g} \mathrm{g}^{-1}$ (Figure 2). The $\mathrm{pH}$ range in the study area has profound environmental - biodegradation - effects on the sixteen PAHs. In the environment PAHs are exposed to degradation via abiotic and or biotic routes, (Earl et al., 2003). In sediments or soil, microbial degradation or metabolism is the major routes of PAHs, (WHO/IPCS, 1998), however, microbial degradation or metabolism is restricted to bio-available fractions in soil-pore water or surfaces of soil particles, (Miller and Alexander, 1991). 
Table 1. Mean Concentration Range of PAHs in the Study Location.

\begin{tabular}{|c|c|c|c|c|c|c|}
\hline \multirow[t]{2}{*}{ Soil PP } & & & & & \multicolumn{2}{|c|}{ SAMPLE STATION } \\
\hline & & & & & $\operatorname{Min}_{c}$ & $\operatorname{Max}_{\mathrm{c}}$ \\
\hline $\mathrm{pH}$ & & & & & 17.18 & G 7.53 \\
\hline TOC & & & & & F 3.39 & G 7.74 \\
\hline Sand & & & & & F 74.44 & I 77.40 \\
\hline Clay & & & & & I 21.61 & D 24.13 \\
\hline Silt & & & & & H 0.80 & F 2.19 \\
\hline \multirow[t]{2}{*}{ PAHs } & & & opertie & & & \\
\hline & Ring & $t^{1} 1 / 2$ & MF & MW & $\operatorname{Min}_{c}$ & Max $_{c}$ \\
\hline Nap & 2 & 6 & $\mathrm{C}_{10} \mathrm{H}_{8}$ & 128.18 & A 0.56 & D 7.31 \\
\hline Acy & 3 & 6 & $\mathrm{C}_{12} \mathrm{H}_{8}$ & 152.20 & G 0.67 & F \& J 2.43 \\
\hline Ace & 3 & 6 & $\mathrm{C}_{12} \mathrm{H}_{10}$ & 154.20 & A 0.83 & H 6.98 \\
\hline Flu & 3 & 6 & $\mathrm{C}_{13} \mathrm{H}_{10}$ & 166.23 & C 0.70 & G 12.91 \\
\hline Phe & 3 & 6 & $\mathrm{C}_{14} \mathrm{H}_{10}$ & 178.24 & B 2.77 & D 33.80 \\
\hline Ant & 3 & 6 & $\mathrm{C}_{14} \mathrm{H}_{10}$ & 178.24 & F 0.33 & A 40.61 \\
\hline Flt & 4 & 7 & $\mathrm{C}_{16} \mathrm{H}_{10}$ & 202.26 & 10.73 & C 14.25 \\
\hline Pyr & 4 & 7 & $\mathrm{C}_{16} \mathrm{H}_{10}$ & 202.26 & 12.60 & G 18.88 \\
\hline Chr & 4 & 7 & $\mathrm{C}_{18} \mathrm{H}_{12}$ & 228.30 & I 1.26 & G 24.48 \\
\hline $\mathrm{B}[\mathrm{a}] \mathrm{a}$ & 4 & 7 & $\mathrm{C}_{18} \mathrm{H}_{12}$ & 228.30 & 10.51 & A 8.521 \\
\hline B[a]p & 5 & 7 & $\mathrm{C}_{20} \mathrm{H}_{12}$ & 252.32 & 10.23 & G 23.97 \\
\hline$B[k] f$ & 5 & 7 & $\mathrm{C}_{20} \mathrm{H}_{12}$ & 252.32 & I 1.06 & H 14.03 \\
\hline$B[k] f$ & 5 & 7 & $\mathrm{C}_{20} \mathrm{H}_{12}$ & 252.32 & I 3.51 & H 16.18 \\
\hline B[ghi]p & 6 & 7 & $\mathrm{C}_{22} \mathrm{H}_{12}$ & 276.34 & I 1.94 & E 129.93 \\
\hline$I[123 c d\} p$ & 6 & 7 & $\mathrm{C}_{22} \mathrm{H}_{12}$ & 276.34 & I 1.37 & F 32.87 \\
\hline $\mathrm{D}[\mathrm{ah}] \mathrm{a}$ & 6 & 7 & $\mathrm{C}_{22} \mathrm{H}_{14}$ & 278.35 & H 8.19 & F 41.57 \\
\hline ¿PAHs & & & & & 160.76 & G 271.19 \\
\hline
\end{tabular}

Were $n=8$

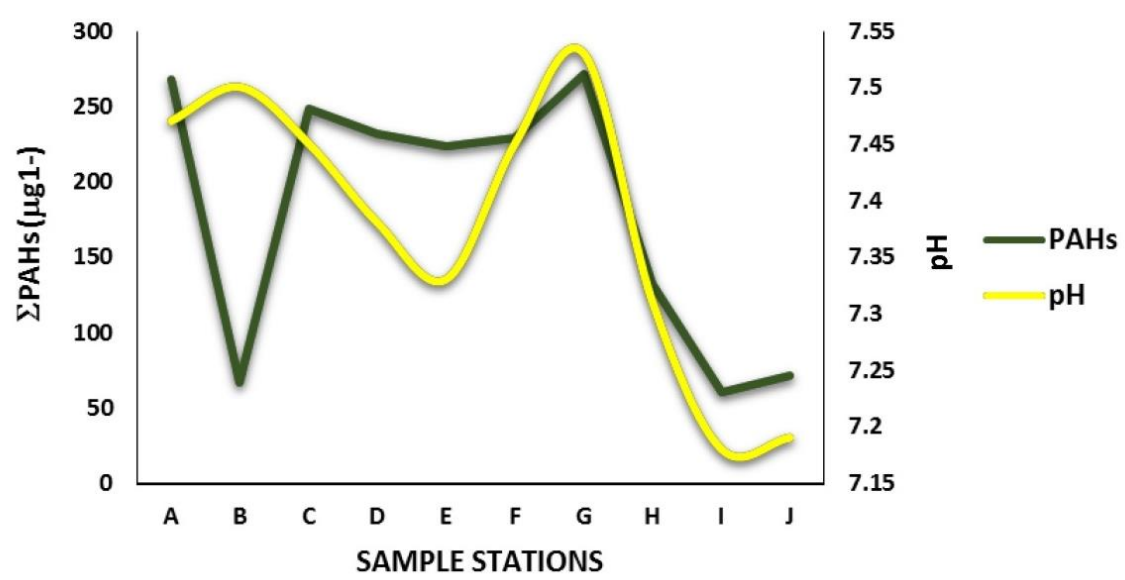

Figure 2. Distribution of $\mathrm{pH}$ and $\sum \mathrm{PAHs}$ in the study area

Pawar et al., (2010) and Okere and Semple (2012), had argued that greater fungal populations are active in soil acidic $\mathrm{pH}$ condition. However, soil alkaline $\mathrm{pH}$ of 8 and 8.5 had higher population compared to neutral $\mathrm{pH}$ of 7.0 and 7.5 with lowest fungal population. Similarly, in acidic soil $\mathrm{pH}$ Pencillium species predominated with lower Aspergiluss population. While in alkaline soil $\mathrm{pH}$ of 8.0 and 8.5, Asperigellus was predominant and Pencillium was not detected, (Pawar et al., 2010, and Okere and Semple, 2012). Research has shown that soil enzymatic actions are high at soil pH of 7.18 - 7.53, (Pawar et al., 2010). This shows that soil $\mathrm{pH}$ in the study area could favor microbial community for the degradation of PAHs. However, observed soil $\mathrm{pH}$ would not favour photo-catalytic degradation since optimal photo-catalytic conditions occur in acidic pH of 6.5, (Pawar, et al., 2010; Yang et al., 2010). Therefore, the rate of photo-catalytic degradation of observed PAHs could be increased by modification of soil with elemental sulfur as it is oxidized by microbes to produce $\mathrm{SO}_{4}{ }^{2-}$ and $\mathrm{H}^{+}$ions, causing acidic $\mathrm{pH}$. Similarly, aluminum Sulfate $\mathrm{Al}_{2}\left(\mathrm{SO}_{4}\right)_{3}$ and $\left(\mathrm{FeSO}_{4}\right)$ could be applied to the acidic cations $\mathrm{Al}^{3+}$ and $\mathrm{Fe}^{2+}$, (Elaton et al., 2001). 
Kruskal-Wallis tied rank test revealed that there was a statistically suggestive difference between $\mathrm{pH}$ and $\Sigma \mathrm{PAHs}$ concentrations since calculated $\mathrm{K}$ is greater than critical $\mathrm{K}_{0.05}$ (i.e. $14.30>3.84$ ), $\mathrm{P}<0.05$, as shown in Table 2.

\subsection{TOC and PAHs Fate}

Results show that there are high concentrations of PAHs, with greater percentages of HPAHs as shown in Table 1 and Figure 3. This could be related to the distribution coefficient - Octanol Water (KOw), Solubility, half-life $\left(\mathrm{t}^{1} / 2\right)$, Henrys' constant and Bio-concentration Factor (BCF) of PAHs. The characteristic distribution of LPAHs and HPAHs in the study area showed that soil TOC favor HPAHs adsorption on active surfaces of the soil which in turn delayed mobilization and leaching of HPAHs. Several studies have shown that organic compounds - PAHs, PCB, dioxine etc - have high level of Kow and low solubility would most likely be retained by soil surface and less susceptible to environmental processes (Valentin et al., Table 2. Comparison of Tied-Kruskall Wallis Test

\begin{tabular}{cccccc}
\hline Comparison & Observed value & Critical value & DF & P-value & alpha \\
\hline $\mathrm{pH}-\sum$ PAHs & 14.30 & 3.84 & 1 & $<0.05$ & 0.05 \\
\hline TOC- $\sum$ PAHs & 14.29 & 3.84 & 1 & $<0.05$ & 0.05 \\
\hline Sand- $\sum$ PAHs & 2.30 & 3.84 & 1 & $>0.05$ & 0.05 \\
\hline Clay- $\sum$ PAHs & 14.29 & 3.84 & 1 & $<0.05$ & 0.05 \\
\hline Silt- $\sum$ PAHs & 14.29 & 3.84 & 1 & $<0.05$ & 0.05 \\
\hline
\end{tabular}

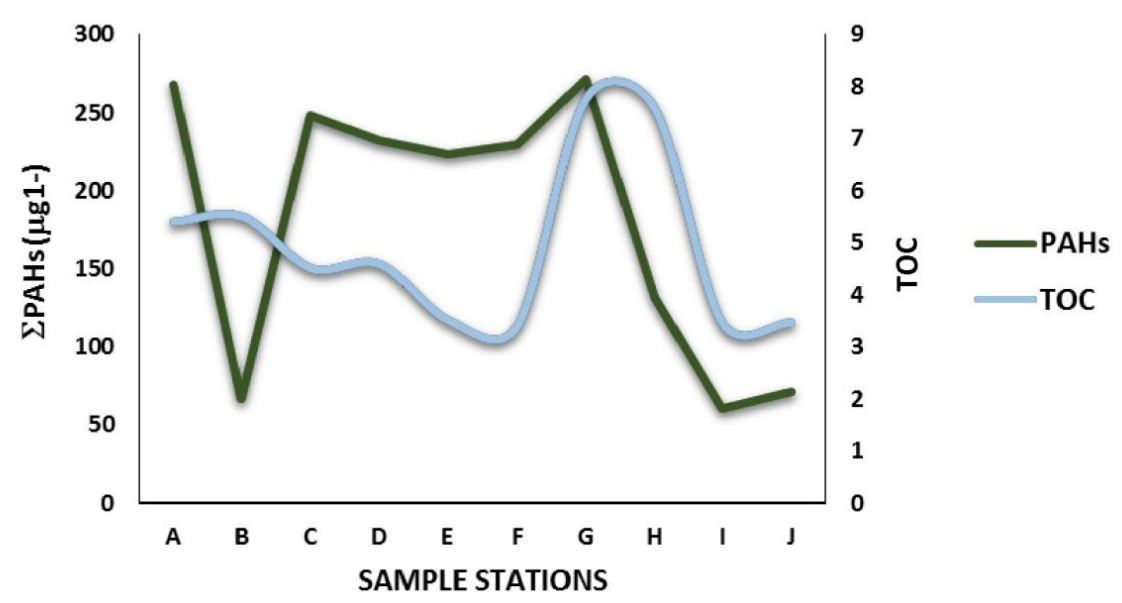

Figure 3. Distribution of TOC and $\angle \mathrm{PAH}$ in the Study area

\subsection{Particle size and PAHs Fate}

The particle size distribution obtained (Table 1 and Figure 4) indicates that the soil consists of about $77 \%$, sand fractions with clay and silt having about $24 \%$ and $2 \%$ respectively. Results of sand fractions in Figure 4 show that there is high concentration of PAHs in all sample stations except stations $\mathrm{B}, \mathrm{I}$ and $\mathrm{J}$, there is similar occurrence in clay and silt fractions. Generally, fine soil particles $(<0.002 \mathrm{~nm})$ have a larger surface area, hence fine soil distribution is a measure of binding or adsorption of contaminants than large particles, (Lewis, 2012).

Research has shown that the characteristics of soil on the biological, chemical and physical, characteristics of each
2013; Petruzzelli et al., 2010). Also, biodegradation and volatilization are slow for HPAHS over LPAHs as observed in Table 1. Several characteristics were correlated with the degradation period, i.e. $\mathrm{t}^{1 / 2}$ of HPAHs are related to the leaching pathway and persistence of HPAHs in the study area. Also, PAHs with LogKow $>4.0$ are rarely mobilized, hence Table 1 shows high percentage of HPAHs. The high percentage of HPAHs in all simple stations could be ascribed to near zero response of HPAHs to photolysis, hydrolysis, volatilization and oxidation. Several researches has shown that these reactions mostly affect molecules having simple molecular structure with reduced complexity such as PAHs<four ring and phenols, (Petruzzelli et al., 2010). Kruskal-Wallis tied rank test revealed that there was a statistically positive correlation between the amount of TOC and $\sum$ PAHs concentration since calculated $\mathrm{K}$ is greater than critical $\mathrm{K}_{0.05}$ (ie. $14.29>3.84$ ), $\mathrm{P}<0.05$, as shown in Table 2 . 
degradation, run-off and leaching, sorption-desorption, volatilization and uptake by plants, (Petruzzelli et al., 2010). Kruskal-Wallis test showed a positive significant difference between the percentage of clay fractions and $\Sigma \mathrm{PAHs}$ concentrations, and percentage of silt fractions and $\sum \mathrm{PAHs}$ concentrations since calculated $\mathrm{K}$ is greater than critical
$\mathrm{K}_{0.05}$ (ie. $14.29>3.84$ and $14.29>3.84$ ) respectively, $\mathrm{P}<0.05$ as shown in Table 2. However, Kruskal-Wallis test revealed that there is no significant correlation between the percentage sand fractions and $\sum \mathrm{PAH}$ concentration since calculated $\mathrm{K}$ is less than critical $\mathrm{K}_{0.05}$ (ie. 2.28>3.84), $\mathrm{P}>0.05$ (Table 2).

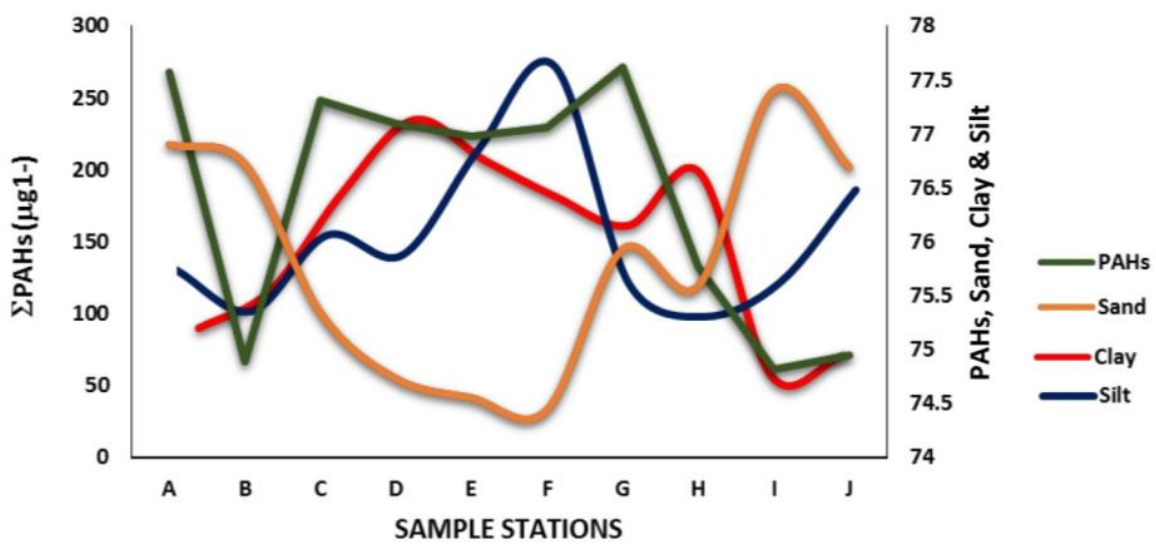

Figure 4. Distribution of Sand, Clay, Silt and $\sum$ PAHs in the study area

\section{Conclusion and Recommendations}

This study shows that the study area is contaminated with varied degrees of PAHs with LogKow $>4.0$ and low solubility and high concentration of HPAHs over LPAHs. Though observed soil $\mathrm{pH}$ would favour microbial degradation of $\mathrm{PAHs}$, combined results of $\mathrm{pH}$ TOC and soil structure could render $\mathrm{PAHs}$ inaccessible for microbial population and significantly limit photo and biochemical degradation. The bioavailability of these contaminants decrease with increase in concentration of TOC, neutral $\mathrm{pH}$ and high percentage of silt. Hence persistence in soil would increase the potential for human and environmental risk of these PPs in the study area. Kruskal-Wallis test also showed that there was a positive significant difference between $\mathrm{pH}$, amount of TOC, percentage clay and silt fractions, and $\sum \mathrm{PAHs}$ concentration since calculated $\mathrm{K}$ is greater than critical $K_{0.05} \mathrm{P}<0.05$ except percentages of sand fractions and $\sum P A H s$, with $P>0.05$. Substantial percentages of these POP have anthropic origin and are characterized as having high lipo-affinity, semi-volatility and resistance to biotic and/or abiotic transformation. Due to edaphic factors, the observed HPAHs may not absorb but can partially degrade with the consequent formation of highly toxic by-products. Therefore, dermal or oral ingestion of soil in the study could cause significant exposure of human population to these PPs. Three-ways bioavailability index evaluation utilized in this study showed PAHs bioavailability and mobility which is of significant interest in bioremediation. Due to transport potentials, the observed PAHs under saturated order, could pose human and environmental risk. Results from this research could be used for hazard identification and risk assessment of probable toxicity effects on animal diversity.

\section{References}

Black C.A. (ed.) (1965): Methods of Soil Analysis Agronomy No, 9, Part 2 American Society of Agronomy, Madison, Wisconsin. (9): 891-901

Bouyoucos G.H. (1951), A Recalibration of the Hydrometer Method for Making Mechanical Analysis of Soils, Agronomy Journal, 430, 434-438.

Cavalcante R.M., Sousa F.W., Nascimento R.F., Silveira E.R. and Freire G.S.S. (2009), The Impact of Urbanization on Tropical Mangroves (Foertaleza, Brazil): Evidence from PAH Distribution in Sediments, Journal of Environmental Management, 91, 328-335.

CCME, (2008). Canadian Soil Quality Guidelines for the Protection of Environmental and Human Health: Benzo [a] Pyrene. In: Canadian Environmental Quality Guidelines. Canadian Council of Ministers of the Environment, Winnipeg, Canada. 235.

Dabestani R. and Ivanov I.N (1999), A Compilation of Physical, Spectroscopic and Photophysical Properties of Polycyclic Aromatic Hydrocarbons (PAHs). In: Photochemistry and Photobiology. Ed. Jean Cadet. 70 (1) 10- 34.

Earl N., Cartwright C.D., Horrocks S.J., Worboys M., Swift S., Kirton A., Askan A.U., Kelleher H. and Nancarrow D.J. (2003), Fate and Transport of Selected Contaminants in the Soil Environment. Draft Technical Report P5-079/TR1. Environmental Agency, Bristol. Pp. 182.

Emoyan O.O. (2014), Quantification and Distribution Characteristics of Polycyclic Aromatic Hydrocarbons (PAHs) in soil Profiles of Western Delta, Nigeria, IOSR Journal of Environmental Science, Toxicology and Food Technology, 8(3)1, 31-39.

Emoyan O.O., Agbaire P.O. and Akporido S.O. (2015b), Variability in Polycyclic Aromatic Hydrocarbons (PAHs) Isomer Pair Ratio: Source Identification Concern, International Journal of Environmental Monitoring and Analysis, 3(3), 111-117.

Emoyan O.O., Akporhonor E.E., Agbaire P.O. and Akporido S.O. (2015c), Concentration Characteristics of Polycyclic Aromatic Hydrocarbons (PAHs) in Dept - Wise Soils, Sapele, Nigeria, 
International Research Journal of Public and Environmental Health, 2(6), 70-79.

Emoyan O.O., Akporido S.O. and Agbaire P.O. (2015a), Seasonal Concentration Variation of Polycyclic Aromatic Hydrocarbons (PAHs) of Soils at Sapele Municipality, Nigeria, American Journal of Environmental Engineering and Science, 2(2), 9-16.

Haygarth P.M and Ritz K. (2009), The Future of Soils and Land use in the UK: Soil Systems for the Provision of Land-Based Ecosystem Services, Elsevier Journal of Land Use Policy, 26S, S187-S197.

Lewis B.G. (2012), Soil Chemistry. In: Environmental and Ecological Chemistry, Encyclopedia of Life Support Systems (EOLSS), 2, 78-115.

Miller M. and Alexander M. (1991), Kinetics of BacterialDegradation of Benzylamine in a Montmorillonite Suspension, Environmental Science and Technology, 25, 240-245.

OIEWG, (1999). Sampling Protocols and Analytical Methods for Determining Petroleum Products in Soil and Water. Ministry for the Environment Wellington. 40.

Okere V.U. and Semple K.T. (2012), Biodegradation of PAHs in "Pristine" Soils from Different Climate Regions, Journal of Bioremediation and Biodegradation, S1:006. doi: 10.4172/2155-6199.S1-006

Opafunson Z.O. (2007), 3D Formation Evolution of an oil Field in the Niger Delta Area of Nigeria using Schlumbeger Petrol Workflow Tool, Journal of Engineering and Applied Sciences, 2(11), 1651-1660.

Pawar R.M, Hall A.M. and Naseby D.C. (2010), Effect of Soil pH on Biodegradation of Polycyclic Aromatic Hydrocarbons, Society of General Microbiology Meeting ENV/02

Petruzzelli G., Gorini F., Pezzarossa B. and F. Pedron (2010), The fate of Pollutants in Soil. In: Environmental Health Interdepartment Project. Eds: Fabrizio B, Liliana C, Pier F. M. Consglio Nazionale delle Ricerche - Roma. 1-31

Robinson D.A., Hockley N., Dominati E., Lebron I., Scow K.M., Reynolds B., Emmett B.A., Keith A.M., de Jonge L.W., Schjønning P., Moldrup P., Jones S.B. and Tuller M. (2012), Natural Capital, Ecosystem Services, and Soil Change: Why Soil Science Must Embrace an Ecosystems Approach, Vadose Zone Journal, 11(1), DOI:10.2136/vzj2011.0051.

Slaton N.A., Norman R.J. and Gilmour J.T. (2001), Oxidation Rates of Commercial Elemental Sulfur Products to an Alkaline Silt Loam from Arkansas, Soil Science, Society of American Journal, 65, 239-243.

Soleimani M., Afyuni M. and Charkhabi A.H. (2013), Transport of Polycyclic Aromatic Hydrocarbons in a Calcareous Wetland Soil, Caspian Journal of Environmental Science, 2, 131-140.

Valentin L., Nousiainen A. and Mikkonen A. (2013), Introduction to Organic Contaminants in soil: Concepts and Risks. In: Emerging Organic Contaminants in Sludges: Analysis, Fate and Biological Treatment. Hand book of Environmental Chemistry. 24. 1-29.

Walkey A. and Black I.A (1934), An Examination of the Degtjareff Method for Determining Soil Organic Matter and Proposed Modification of the Chromic Acid Titration Method, Soil Sc., 37, 39-38.

WHO/IPCS, (1998). Environmental Health Criteria 202: Selected Non-Heterocyclic Polycyclic Aromatic Hydrocarbon. International Program on Chemical Safety, United Nations Environmental Program, World Health Oganization. Geneva. 883.
World Health Oganization. (2002). Health Risk of Persisent Organics Pollutants from Long-Range Transboundary Air Pollution. European Centre for Environment and Health. Bonn. 200.

Xu J., Kleja D.B., Biester H., Lagerkvist A. and Kumpiene J. (2014), Influence of Particle Size Distribution, Organic Carbon, $\mathrm{pH}$ and Chlorides on Washing of Mercury Contaminated Soil, Chemosphere, 109, 99-105.

Yang Y., Tao S., Zhang N., Zhang D.Y. and Li X.Q (2010), The Effect of Soil Organic Matter on Fate of Transport of Polycyclic Aromatic Hydrocarbons in Soil: A Microcosm Study, Environment Pollution, 158, 1768-1774.

Zeng Y., Hong P.K.A. and Wavrek D.A. (2000), Integrated Chemical-Biological Treatment of B[a]p, Environmental Science and Technology, 34, 854-862. 